\title{
Business Historical Society Broadcast
}

During the past month both Mr. Howard Corning, Curator of the Manuscript Department of the George F. Baker Library, and Mr. Frank C. Ayres, Secretary of the Business Historical Society, spoke over stations WBZ, WBZA and WIXAZ. This broadcast was arranged through the courtesy of Mr. E. J. Rowell, Coöperative Representative of the New England Radio Market News Service.

Mr. Corning's talk, which was given at noon Friday, March 6, was entitled "Sources of New England's Industrial History," and dealt with the manuscript material in the Baker Library, including the material belonging to the Business Historical Society. He discussed at some length the importance of business history and made an appeal to the public for old account books, home work receipts, etc., relating to that phase in our industrial history when the farmer, in order to augment his income, had been forced to carry on other trades in his home, such as making shoes, weaving straw hats and running a small store. Material pertaining to the "putting-out" system, when the wives and daughters took in work from the textile factories in the district to be finished into garments, was also stressed as being of great importance in forming a basis for one phase of business history of this country.

Mr. Ayres spoke on Friday, March ${ }^{3} 3$, at the same hour and discussed "The Importance of Farm and General Store Account Books in Business History." An article on this subject appeared in the last edition of the Bulletin. Mr. Ayres directed his appeal to the housewives who, while engaged in their spring cleaning, might come across such account books in old trunks and boxes stored away in forgotten corners and attics. The importance of such material to the student of business cycles was particularly emphasized.

\section{German Inflation Currency}

There is an old saying that "every cloud has a silver lining," but no doubt it must have been difficult for German business men to see any ray of hope during the dark years succeeding the war when the mark plunged down on the exchange until it was practically worthless. In fact, never in the history of the world has a currency depreciated to such a degree. Statistics show that four hundred German marks were worth \$95.I25 (as quoted on the New York Exchange) in June, I9I4; this figure had dropped to $\$ 50.445$ (as 